\title{
The Effect of Training, Competence and Compensation on the Peformance of New Civil Servants with Organizational Culture as Intervening: Studies at the Ministry of Health of the Republic of Indonesia
}

\author{
Edi Sugiono', Suryono Efendi ${ }^{2}$, Yani Afrina ${ }^{3}$ \\ 1,2,3 Universitas Nasional Jakarta, Indonesia \\ Email: edisugiono33@yahoo.com
}

\begin{abstract}
The Coronavirus pandemic is a severe problem throughout 2020 for the whole world, including Indonesia. The Coronavirus pandemic question is not only about the virus, which makes the health of an individual decrease, but in several countries, including Indonesia, the existence of the coronavirus pandemic has put the health ministry's performance in the spotlight because the coronavirus pandemic is related to health. Many have speculated that the increasing coronavirus pandemic in Indonesia is due to the Ministry of Health's slow performance in preventing the Coronavirus pandemic. This research uses quantitative methods with a descriptive analysis approach. The questionnaire uses a closed questionnaire presented in a question or statement equipped with alternative responses/answers. This research's analysis method is the quantitative analysis method using Structural Equation Model (SEM). This study shows that training is proven to have a positive and real effect on the Ministry of Health's organizational culture, meaning that the Ministry of Health's increasing practice will improve the Ministry of Health employees' corporate culture. This influence is determined by the training held by BBPK Jakarta for employees of the Ministry of Health to form employees with an excellent organizational culture.
\end{abstract}

Keywords: Performance, Civil Servants, Organizational Culture, Intervention.

\section{A. INTRODUCTION}

The coronavirus pandemic (Covid-19) is a thorny problem throughout 2020 for the whole world, including Indonesia. The question of the coronavirus pandemic (Covid-19) is not only about the virus which makes the health of an individual decrease, but in several countries, including Indonesia, the existence of the coronavirus pandemic (Covid-19) has made the performance of the Ministry of health in the spotlight, because of the coronavirus pandemic (Covid-19) related to health. Many have speculated that the increasing coronavirus (Covid-19) pandemic in Indonesia is due to the slow performance of the Ministry of Health in preventing the coronavirus (Covid-19) pandemic (Amir, 2017).

The negative stigma from the public towards the Ministry of Health regarding the performance of civil servants, especially those working in the Ministry of Health environment. In 2020, the main topic of Covid-19 became the discussion of the Ministry of Health's performance. Still, the Ministry of Health's performance report in 2019 shows that the 2018 and 2019 targets were not achieved, the achievement of 
work activity indicators in 42017 was 141.29\%, 2018 was 110, 11\%, and in 2019 $92.71 \%$. The 2019 target was not achieved. This means that the Ministry of Health's performance has not been going well (Febrina, 2019).

Based on data from the Personnel Bureau, the performance of employees at the Ministry of Health has increased, this can be seen from the percentage of employees whose performance gets a good minimum score as follows:

Table 1. Percentage of Ministry of Health Employees with Minimum Good

Performance Value in 2015-2019

\begin{tabular}{|c|c|c|}
\hline Year & Target & Realization \\
\hline 2015 & $80 \%$ & $85,45 \%$ \\
\hline
\end{tabular}

From Table 1 above, the performance of Ministry of Health employees increases each year. However, this applies as a whole to the Ministry of Health both at the central level and in its technical implementing units (Setiawan, 2013). However, for employees who provide health services such as doctors/specialists, nurses, midwives, public health, and so on, this is not the case (Ningsi, 2016). From the staffing data at the directorate general of health services, the presentation of employees who get good performance scores is as follows:

Table 2. Percentage of Directorate General Health Service Employee Performance

Based on SKP Assessment 2015-2019

\begin{tabular}{|c|c|c|}
\hline Year & Target & Realization \\
\hline 2015 & $80 \%$ & $88,89 \%$ \\
\hline 2016 & $85 \%$ & $92,46 \%$ \\
\hline 2017 & $88 \%$ & $99,68 \%$ \\
\hline 2018 & $91 \%$ & $99,39 \%$ \\
\hline 2019 & $94 \%$ & $98,75 \%$ \\
\hline
\end{tabular}

Source: Directorate General of Health Services, Ministry of Health

From table 2, the employee performance of the Directorate of Health Services of the Ministry of Health from 2015-2017 has increased in employee performance scores. Still, there has been a decline in employee performance at the Directorate General of Health Services from 2018 to 2019, even though it always exceeds the target of achieving a minimum good employee performance value. It was targeted by the Personnel Bureau (State Administration Institute, 2018). This shows a decrease in employee performance for employees of the directorate general of health services.

Employee performance has a vital role in supporting the organization's success and success; if employee performance is low, it will hurt organizational performance (Robbins, 2015). Many factors affect performance, including training, competence, motivation, leadership, and job satisfaction. Factors that influence performance include cultural factors, training, and work motivation (Sanusi, 2011).

In the last five years, the acceptance of CPNS has been filled with job seekers at the age of what is said to be the "millennial generation" (Saraswati, 2019). With the emergence of millennial CPNS, there is hope that the bureaucracy will be more 
qualified and faster because millennials have a quality orientation, use technology, and the internet, and are agile and quick to complete work (Mawardi, 2010). However, millennial characteristics that are feared will be an obstacle to realizing these hopes, namely their individualistic behavior, egalitarianism, and different ways of communicating with senior bureaucrats. One of the efforts so that these millennial CPNS can be directed to the correct orientation following the hope that they become the motor of change in the bureaucracy is through training (Sari, 2018).

The Jakarta Center for Health Training (BBPK) is one of the government training institutions belonging to the Ministry of Health, which has the primary task and function of providing training for civil servants and the public to develop employee competencies. Education and Pre-Service Training/Basic CPNS Training is a training that is routinely held every year. The main target of training participants at BBPK Jakarta is, of course, CPNS who work at the Ministry of Health (Sembiring, 2016). Many pre-service training participants who have been trained at BBPK Jakarta work as civil servants in various work units within the Ministry of Jakarta. Each year the number of CPNS trained at BBPK Jakarta is an average of 420 people.

Since 2017, Education and Pre-Service Training has changed its name to Basic Training for Prospective Civil Servants, where the learning model follows a new pattern. In this training, the training participants learn at the training institute and carry out actualization and habituation (habituation) in the workplace guided by a mentor who is their direct supervisor. As a result of this habituation, training participants must present their actualized results to pass the training. This training aims to develop CPNS competencies, which are carried out in an integrated manner to form CPNS who have a national character and are professional in their fields. CPNS Basic Training Alumni are expected to be honest, have a feeling, be loyal to the nation and state, and professionals in their fields according to the Indonesian people's aspirations.

Another factor that can affect employee performance is employee competency. Competence is an element of readiness related to knowledge and skills obtained from education, training, and experience. Thus, competence shows skills and knowledge characterized by professionalism in a particular field as the most important thing or superior in that field (Pujimulyatama, 2014). Because, in general, competence concerns a person's fundamental ability to do work. Competence is indispensable in every human resource process (Sinambela, 2016). The more competencies an employee has, the more the employee's enthusiasm for work will increase.

Another factor that can improve employee performance and foster employee morale is compensation. Employees work to get a reward or prize. Errors in implementing the compensation system will result in demotivation and lack of job satisfaction among workers. Inadequate compensation can affect a person's performance. There are still many complaints that civil servants' salaries are not enough to live correctly. Also, organizational culture can affect a person's account. For CPNS who has just been appointed to a new place, of course, they must follow 
the corporate culture that applies in their workplace. This can affect performance. For young employees and millennials who have their mindset, this can affect their interpretation. There are still many superiors and seniors who come from the generation above them, so there is a gap (Dessler, 2015).

Organizational culture factors are also factors that can affect performance. Corporate culture has an essential role in determining an administrative change in which the organization can grow and develop because the organizational culture can stimulate employee morale in the organization to improve its performance. In this case, the corporate culture that is built must be supported by employee performance. Their work will be more focused because good employee performance reflects a person's sense of responsibility for the assigned tasks. The strong organizational culture can be seen in how employees perceive culture to affect behavior, described through dedication, creativity, ability, discipline, and high commitment. In this study, organizational culture is also used as an intervening variable, and researchers want to see how training, competence, and compensation directly influence performance and indirectly through corporate culture.

Research shows that the results of training have a positive and significant effect on employee performance. The direct impact is $25.3 \%$ then research, with the study results showing that partially organizational culture, training, and motivation influence performance. Simultaneously, corporate culture, training, and inspiration significantly influence performance (Busro, 2018). Meanwhile, other research shows that exercise does not have a substantial effect on performance.

Research that shows competence affects employee performance, such as research (Dhermawan, 2012), with the results of competence having a positive and significant effect on the performance of employees of PT. Asuransi Jiwa Bringin Jiwa Sejahtera (BRIlife). Research by Kurniawan et al. (2018), with Results competence and motivation directly and significantly affects employee performance either with the F-test or partially with the T-test. But the correlation is not strong enough. Competence and motivation positively affected employee performance considerably, both with the F test and somewhat with the T-test. But the correlation is less intense. Meanwhile, research shows that competence has no significant effect on Maryesa's performance (Manurung, 2013).

Research that shows compensation affects employee performance, such as research by Kusuma \& Ardana (2012), with the results of the study finding that there is a positive and significant effect directly between placement, compensation on job satisfaction and direct influence of order, payment, and happiness. Work on employee performance. Furthermore, it was found that indirect placement and balance affected employee performance through job satisfaction. There was a total influence between placement and compensation on employee performance through employee job satisfaction. Meanwhile, Ika Shofi Arhama's research (2017) shows that settlement does not affect employee performance as evidenced by the value of $t_{\text {count }}>$ table, so Ho is accepted. 
Research that shows organizational culture affects employee performance, such as research by Maryesa (2016), Sukmawati \& Wijayanto (2016), with the results of corporate culture having a significant effect on the Competence of LAPAN employees ( $\mathrm{H}$ accepted). The consequences of competence, communication, and organizational culture significantly affect performance through employee satisfaction at the revenue and financial management office of Brebes district. Training, competence, motivation, and organizational culture significantly affect performance. Meanwhile, research (Girsang 2019) shows that corporate culture has no significant effect on Putri Hijau Hospital's employee performance (Katidjan, 2018).

\section{B. METHOD}

This research design was conducted quantitatively with a descriptive analysis research method. In this study, the types of data presented are primary data and secondary data. Preliminary data were collected directly in the field. Primary data sources were obtained from the results of distributing questionnaires to respondents. The questionnaire uses a closed questionnaire presented in the form of a question or statement equipped with alternative responses/answers. This questionnaire contains two main sections. In this study, primary data were the respondents' answers, while secondary data were historical data of participants at BBPK Jakarta. Data collection techniques can be done using interviews, questionnaires, and observations. The data collection method used was a questionnaire (Sugiyono, 2012). This research's analysis method is a quantitative analysis method using Structural Equation Model (SEM), where the causality relationship between exogenous and endogenous variables can be determined more fully.

\section{RESULT AND DISCUSSION}

The Ministry of Health is one of the ministries that assist the president in dealing with Indonesia's health problems. In the 2019-2024 government period, which has a vision of "Creating healthy, productive, independent and just human beings." To help run government programs in the health sector. There are an organizational structure and work procedure following Regulation of the Minister of Health Number 25 of 2020. Following its primary duties and functions, the organizational structure of the Ministry of Health consists of 1) Secretariat General; 2) Directorate General of Public Health; 3) Directorate General of Disease Prevention and Control; 4) Directorate General of Health Services; 5) Directorate General of Pharmaceuticals and Medical Devices; 6) Inspectorate General; 7) Health Research and Development Agency; 8) Human Resources Development and Empowerment Agency; 9) Expert Staff for Health Economics; 10) Expert Staff for Health Technology and Globalization; 11) Expert Staff for Health Decentralization; 12) Expert Staff for Health Law; 13) Data and Information Center; 14) Center for Health Determinants Analysis; 15) Center for Financing and Health Insurance; 16) Health Crisis Center; and 17) Hajj Health Center (Muharam, 2019). 


\section{Research Respondents}

Below is the distribution of respondents based on gender groups which are presented in the following table:

Table 3. Characteristics of Respondents by Gender

\begin{tabular}{|c|c|c|}
\hline Characteristics & Amount & Percentage (\%) \\
\hline Male & 91 & 45.5 \\
\hline Female & 109 & 54.5 \\
\hline
\end{tabular}

Source: Data Processing 2020

Below is the distribution of respondents by age group, which is presented in the following table:

Table 4. Characteristics of Respondents by Age

\begin{tabular}{|c|c|c|}
\hline Characteristics & Amount & Percentage (\%) \\
\hline$<=25$ years old & 39 & 19.5 \\
\hline 26-30 years old & 78 & 39.0 \\
\hline 31-35 years old & 61 & 30.5 \\
\hline$>35$ years old & 22 & 11.0 \\
\hline
\end{tabular}

Source: Data Processing 2020

Below is the distribution of respondents based on the latest education group, which is presented in the following table:

Table 5. Characteristics of Respondents Based on Recent Education

\begin{tabular}{|l|c|c|}
\hline \multicolumn{1}{|c|}{ Characteristics } & Amount & Percentage (\%) \\
\hline Medical & 25 & 12.5 \\
\hline Specialist & 26 & 13.0 \\
\hline Nutrition & 11 & 5.5 \\
\hline Nursing & 41 & 20.5 \\
\hline Public health & 18 & 9.0 \\
\hline Ners & 15 & 7.5 \\
\hline Pharmacy & 28 & 14.0 \\
\hline Etc. & 36 & 18.0 \\
\hline
\end{tabular}

Source: Data Processing 2020

The results of the descriptive analysis of the respondents' answers to each indicator of the training variables are presented in the following table:

Table 6. Results of the Descriptive Analysis of Training Variables

\begin{tabular}{|c|c|c|c|c|c|c|c|c|c|c|c|c|c|c|}
\hline \multirow{3}{*}{ Indicator } & \multirow{3}{*}{ Item } & \multicolumn{10}{|c|}{ Answer Score } & \multirow{3}{*}{ Amount } & \multirow{3}{*}{$\begin{array}{l}\text { Mean } \\
\text { Item }\end{array}$} & \multirow{3}{*}{$\begin{array}{c}\text { Mean } \\
\text { Indicator }\end{array}$} \\
\hline & & \multicolumn{2}{|c|}{ (1) SD } & \multicolumn{2}{|c|}{ (2) $\mathrm{Di}$} & \multicolumn{2}{|c|}{ (3) Do } & \multicolumn{2}{|c|}{ (4) $\mathrm{A}$} & \multicolumn{2}{|c|}{ (5) SA } & & & \\
\hline & & $\mathrm{F}$ & $\%$ & $\mathrm{~F}$ & $\%$ & $\mathrm{~F}$ & $\%$ & $\mathrm{~F}$ & $\%$ & $\mathrm{~F}$ & $\%$ & & & \\
\hline \multirow{2}{*}{ Curriculum } & X1.1 & 0 & $0 \%$ & 38 & $19 \%$ & 58 & $29 \%$ & 58 & $29 \%$ & 46 & $23 \%$ & 712 & 3.6 & \multirow{2}{*}{3.6} \\
\hline & X1.2 & 0 & $0 \%$ & 21 & $11 \%$ & 74 & $37 \%$ & 56 & $28 \%$ & 49 & $25 \%$ & 733 & 3.7 & \\
\hline \multirow{2}{*}{ Method } & X1.3 & 0 & $0 \%$ & 26 & $13 \%$ & 73 & $37 \%$ & 69 & $35 \%$ & 32 & $16 \%$ & 707 & 3.5 & \multirow{2}{*}{3.6} \\
\hline & X1.4 & 0 & $0 \%$ & 28 & $14 \%$ & 61 & $31 \%$ & 64 & $32 \%$ & 47 & $24 \%$ & 730 & 3.7 & \\
\hline \multirow{2}{*}{ Coaches } & X1.5 & 0 & $0 \%$ & 29 & $15 \%$ & 75 & $38 \%$ & 58 & $29 \%$ & 38 & $19 \%$ & 705 & 3.5 & \multirow{2}{*}{3.5} \\
\hline & X1.6 & 0 & $0 \%$ & 43 & $22 \%$ & 55 & $28 \%$ & 67 & $34 \%$ & 35 & $18 \%$ & 694 & 3.5 & \\
\hline Evaluation / & X1.7 & 0 & $0 \%$ & 17 & $9 \%$ & 63 & $32 \%$ & 84 & $42 \%$ & 36 & $18 \%$ & 739 & 3.7 & 3.7 \\
\hline
\end{tabular}




\begin{tabular}{|c|c|c|c|c|c|c|c|c|c|c|c|c|c|c|}
\hline \multirow{3}{*}{ Indicator } & \multirow{3}{*}{ Item } & \multicolumn{10}{|c|}{ Answer Score } & \multirow{3}{*}{ Amount } & \multirow{3}{*}{$\begin{array}{c}\text { Mean } \\
\text { Item }\end{array}$} & \multirow{4}{*}{$\begin{array}{l}\text { Mean } \\
\text { Indicator }\end{array}$} \\
\hline & & \multicolumn{2}{|c|}{ (1) SD } & \multicolumn{2}{|c|}{ (2) Di } & \multicolumn{2}{|c|}{ (3) Do } & \multicolumn{2}{|c|}{ (4) $\mathrm{A}$} & \multicolumn{2}{|c|}{ (5) SA } & & & \\
\hline & & $\mathrm{F}$ & $\%$ & $\mathrm{~F}$ & $\%$ & $\mathrm{~F}$ & $\%$ & $\mathrm{~F}$ & $\%$ & $\mathrm{~F}$ & $\%$ & & & \\
\hline assessment & $\mathrm{X} 1.8$ & 0 & $0 \%$ & 19 & $10 \%$ & 57 & $29 \%$ & 83 & $42 \%$ & 41 & $21 \%$ & 746 & 3.7 & \\
\hline
\end{tabular}

Source: Data Processing 2020

Table 6 shows that most respondents answered agree (34\%). The analysis results on the average of all respondents' answers to the training variable amounted to 3.6. The results above show that the highest training is on the evaluation/assessment indicator, which is 3.7, and the lowest is on the Trainer indicator, which is 3.5. These results can be illustrated in the following diagram:

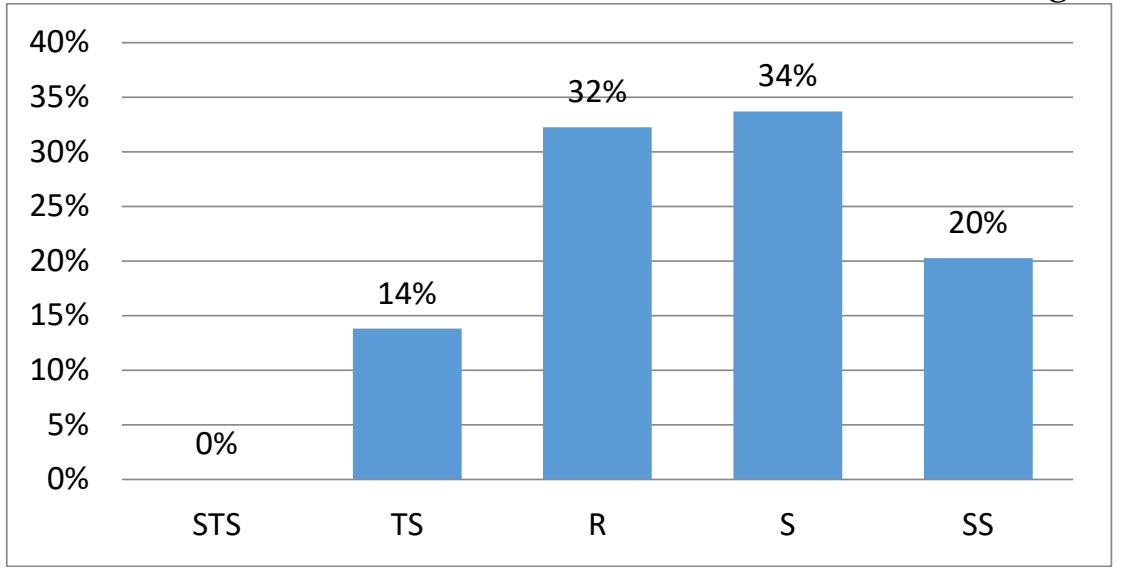

Source: Data Processing 2020

Figure 1. Distribution of Answers on Training Variables

The diagram above shows that the results of the distribution of the highest training answers are the agreed answers, which is $34 \%$, and the lowest marks are the disagree answers, namely $14 \%$. The interviews with employees stated that they are more pleased with a curriculum that can make it easier to do assignments. Of course, the methods used can further improve skills and trainers in delivering easy-tounderstand material so that evaluation or assessment of employee performance can be enhanced (Sultana, 2012). The results of descriptive analysis of respondents' answers to each variable competency indicator are presented in the following table:

Table 7. Results of the Descriptive Analysis of Competency Variables

\begin{tabular}{|c|c|c|c|c|c|c|c|c|c|c|c|c|c|c|}
\hline \multirow{3}{*}{ Indicator } & \multirow{3}{*}{ Item } & \multicolumn{10}{|c|}{ Answer Score } & \multirow{3}{*}{ Amount } & \multirow{3}{*}{$\begin{array}{c}\text { Mean } \\
\text { Item }\end{array}$} & \multirow{3}{*}{$\begin{array}{l}\text { Mean } \\
\text { Indicator }\end{array}$} \\
\hline & & \multicolumn{2}{|c|}{ (1) SD } & \multicolumn{2}{|c|}{ (2) $\mathrm{Di}$} & \multicolumn{2}{|c|}{ (3) $\mathrm{Do}$} & \multicolumn{2}{|c|}{ (4) $\mathrm{A}$} & \multicolumn{2}{|c|}{ (5) SA } & & & \\
\hline & & $\mathrm{F}$ & $\%$ & $\mathrm{~F}$ & $\%$ & $\mathrm{~F}$ & $\%$ & $\mathrm{~F}$ & $\%$ & $\mathrm{~F}$ & $\%$ & & & \\
\hline \multirow{3}{*}{ Knowledge } & X2.1 & 1 & $1 \%$ & 1 & $1 \%$ & 38 & $19 \%$ & 67 & $34 \%$ & 93 & $47 \%$ & 850 & 4.3 & \multirow{3}{*}{4.2} \\
\hline & $\mathrm{X} 2.2$ & 1 & $1 \%$ & 10 & $5 \%$ & 37 & $19 \%$ & 82 & $41 \%$ & 70 & $35 \%$ & 810 & 4.1 & \\
\hline & $\mathrm{X} 2.3$ & 3 & $2 \%$ & 5 & $3 \%$ & 31 & $16 \%$ & 79 & $40 \%$ & 82 & $41 \%$ & 832 & 4.2 & \\
\hline \multirow{3}{*}{ Skills } & $\mathrm{X} 2.4$ & 3 & $2 \%$ & 3 & $2 \%$ & 50 & $25 \%$ & 72 & $36 \%$ & 72 & $36 \%$ & 807 & 4.0 & \multirow{3}{*}{3.9} \\
\hline & $\mathrm{X} 2.5$ & 3 & $2 \%$ & 15 & $8 \%$ & 40 & $20 \%$ & 63 & $32 \%$ & 79 & $40 \%$ & 800 & 4.0 & \\
\hline & X2.6 & 3 & $2 \%$ & 3 & $2 \%$ & 69 & $35 \%$ & 83 & $42 \%$ & 42 & $21 \%$ & 758 & 3.8 & \\
\hline \multirow{3}{*}{ Ability } & X2.7 & 1 & $1 \%$ & 5 & $3 \%$ & 83 & $42 \%$ & 87 & $44 \%$ & 24 & $12 \%$ & 728 & 3.6 & \multirow{3}{*}{3.6} \\
\hline & $\mathrm{X} 2.8$ & 1 & $1 \%$ & 5 & $3 \%$ & 89 & $45 \%$ & 77 & $39 \%$ & 28 & $14 \%$ & 726 & 3.6 & \\
\hline & X2.9 & 5 & $3 \%$ & 17 & $9 \%$ & 92 & $46 \%$ & 56 & $28 \%$ & 30 & $15 \%$ & 689 & 3.4 & \\
\hline
\end{tabular}

Source: Data Processing 2020 
Table 7 shows that most respondents answered agree (37\%). The analysis results on the average of all respondents' answers to the competency variable amounted to 3.8. The results above show that the highest competency is in the knowledge indicator, which is 4.2 , and the lowest is on the ability indicator, which is 3.6. These results can be illustrated in the following diagram:

The diagram above shows that the highest competency answers on the agreed answers are $37 \%$, and the lowest effects on the solutions strongly disagree, namely $1 \%$. The results of an interview with Anik Sri Handayani from the Personnel Bureau of the Ministry of Health, that in accepting employees according to the applicable law, several stages must be passed, of course, these stages are to assess the knowledge, skills, and abilities of employees (Government of Indonesia, 2019). It also aims to make employees know about job desk jobs, responsibilities, and values in substance. The results of the descriptive analysis of the respondents' answers to each indicator of the compensation variable are presented in the following table:

Table 8. Results of the Descriptive Analysis of Compensation Variables

\begin{tabular}{|c|c|c|c|c|c|c|c|c|c|c|c|c|c|c|}
\hline \multirow{3}{*}{ Indicator } & \multirow{3}{*}{ Item } & \multicolumn{10}{|c|}{ Answer Score } & \multirow{3}{*}{ Amount } & \multirow{3}{*}{$\begin{array}{l}\text { Mean } \\
\text { Item }\end{array}$} & \multirow{3}{*}{$\begin{array}{c}\text { Mean } \\
\text { Indicator }\end{array}$} \\
\hline & & \multicolumn{2}{|c|}{ (1) SD } & \multicolumn{2}{|c|}{ (2) Di } & \multicolumn{2}{|c|}{ (3) Do } & \multicolumn{2}{|c|}{ (4) A } & \multicolumn{2}{|c|}{ (5) SA } & & & \\
\hline & & $\mathrm{F}$ & $\%$ & $\mathrm{~F}$ & $\%$ & $\mathrm{~F}$ & $\%$ & $\mathrm{~F}$ & $\%$ & $\mathrm{~F}$ & $\%$ & & & \\
\hline \multirow{2}{*}{$\begin{array}{c}\text { Wages and } \\
\text { salaries }\end{array}$} & X3.1 & 0 & $0 \%$ & 4 & $2 \%$ & 24 & $12 \%$ & 95 & $48 \%$ & 77 & $39 \%$ & 845 & 4.2 & \multirow{2}{*}{4.2} \\
\hline & $\mathrm{X} 3.2$ & 0 & $0 \%$ & 1 & $1 \%$ & 51 & $26 \%$ & 79 & $40 \%$ & 69 & $35 \%$ & 816 & 4.1 & \\
\hline \multirow{2}{*}{$\begin{array}{c}\text { Incentives/ } \\
\text { Bonuses }\end{array}$} & X3.3 & 0 & $0 \%$ & 2 & $1 \%$ & 41 & $21 \%$ & 85 & $43 \%$ & 72 & $36 \%$ & 827 & 4.1 & \multirow{2}{*}{4.1} \\
\hline & X3.4 & 0 & $0 \%$ & 1 & $1 \%$ & 44 & $22 \%$ & 96 & $48 \%$ & 59 & $30 \%$ & 813 & 4.1 & \\
\hline \multirow{2}{*}{ Allowance } & $\mathrm{X} 3.5$ & 25 & $13 \%$ & 19 & $10 \%$ & 56 & $28 \%$ & 50 & $25 \%$ & 50 & $25 \%$ & 681 & 3.4 & \multirow{2}{*}{3.7} \\
\hline & X3.6 & 0 & $0 \%$ & 1 & $1 \%$ & 41 & $21 \%$ & 104 & $52 \%$ & 54 & $27 \%$ & 811 & 4.1 & \\
\hline \multirow{2}{*}{ Amenities } & X3.7 & 1 & $1 \%$ & 4 & $2 \%$ & 63 & $32 \%$ & 79 & $40 \%$ & 53 & $27 \%$ & 779 & 3.9 & \multirow{2}{*}{3.9} \\
\hline & X3.8 & 1 & $1 \%$ & 0 & $0 \%$ & 65 & $33 \%$ & 81 & $41 \%$ & 53 & $27 \%$ & 785 & 3.9 & \\
\hline
\end{tabular}

Source: Data Processing 2020

Table 8 shows that most of the respondents answered agree (42\%). The analysis results on the average of all respondents' answers to the compensation variable amounted to 4.0. The results above show that the highest compensation is in the Wage and salary indicator, which is 4.2, and the lowest is in the Allowance indicator, which is 3.7. These results can be illustrated in the following diagram:

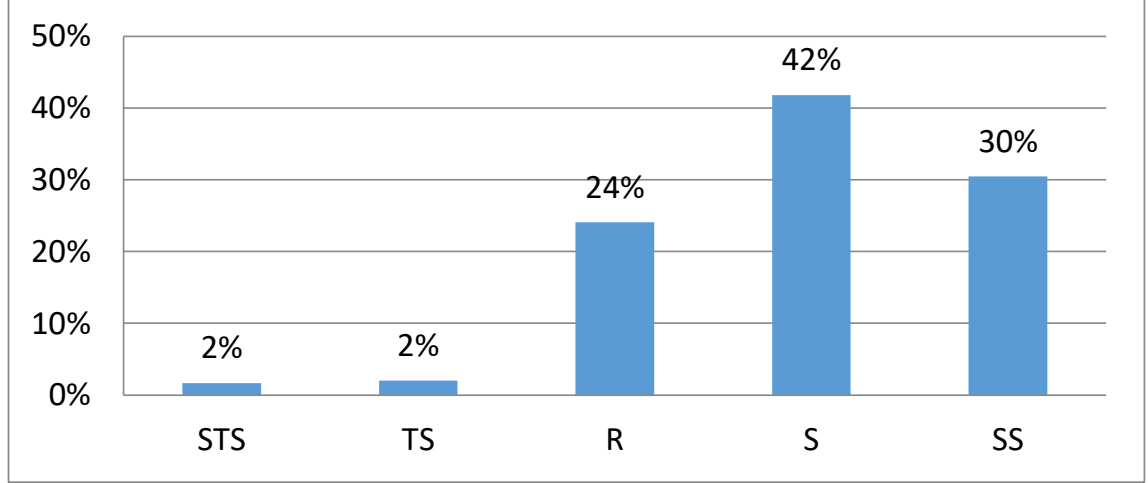

Source: Data Processing 2020

Figure 2. Distribution of Answers on the Compensation Variable 
The diagram above shows that the highest compensation answers' distribution results are on the agreed answers, which is $42 \%$, and the lowest effects on the solutions strongly disagree and disagree, namely $2 \%$.

Things that need to be considered in compensation are wages and salaries of employees, bonuses, allowances, and facilities. Everyone works to make themselves and their families prosperous and meet their needs, especially their basic needs. The results of interviews with several employees with different lengths of work stated that working in the Ministry of health with the salary given can meet the needs and bonuses given according to the employee's performance, the benefits provided are also appropriate and not excessive, and facilities in the form of promotion opportunities get the same chance.

The results of descriptive analysis of respondents' answers to each indicator of the employee performance variables are presented in the following table:

Table 9. Results of the Descriptive Analysis of Employee Performance Variables

\begin{tabular}{|c|c|c|c|c|c|c|c|c|c|c|c|c|c|c|}
\hline \multirow{3}{*}{ Indicator } & \multirow{3}{*}{ Item } & \multicolumn{10}{|c|}{ Answer Score } & \multirow{3}{*}{ Amount } & \multirow{3}{*}{$\begin{array}{c}\text { Mean } \\
\text { Item }\end{array}$} & \multirow{3}{*}{$\begin{array}{c}\text { Mean } \\
\text { Indicato }\end{array}$} \\
\hline & & \multicolumn{2}{|c|}{ (1) SD } & \multicolumn{2}{|c|}{ (2) $\mathrm{Di}$} & \multicolumn{2}{|c|}{ (3) Do } & \multicolumn{2}{|c|}{ (4) $\mathrm{A}$} & \multicolumn{2}{|c|}{ (5) SA } & & & \\
\hline & & $\mathrm{F}$ & $\%$ & $\mathrm{~F}$ & $\%$ & $\mathrm{~F}$ & $\%$ & F & $\%$ & $\mathrm{~F}$ & $\%$ & & & \\
\hline \multirow{3}{*}{$\begin{array}{l}\text { Work } \\
\text { result }\end{array}$} & $\mathrm{Y} 1$ & 0 & $0 \%$ & 5 & $3 \%$ & 32 & $16 \%$ & 84 & $42 \%$ & 79 & $40 \%$ & 837 & 4.2 & \multirow{3}{*}{4.2} \\
\hline & $\mathrm{Y} 2$ & 15 & $8 \%$ & 4 & $2 \%$ & 26 & $13 \%$ & 58 & $29 \%$ & 97 & $49 \%$ & 818 & 4.1 & \\
\hline & Y3 & 0 & $0 \%$ & 6 & $3 \%$ & 12 & $6 \%$ & 104 & $52 \%$ & 78 & $39 \%$ & 854 & 4.3 & \\
\hline \multirow{3}{*}{$\begin{array}{c}\text { Work } \\
\text { behavior }\end{array}$} & Y4 & 0 & $0 \%$ & 4 & $2 \%$ & 75 & $38 \%$ & 84 & $42 \%$ & 37 & $19 \%$ & 754 & 3.8 & \multirow{3}{*}{3.6} \\
\hline & Y5 & 0 & $0 \%$ & 13 & $7 \%$ & 85 & $43 \%$ & 73 & $37 \%$ & 29 & $15 \%$ & 718 & 3.6 & \\
\hline & $\mathrm{Y} 6$ & 0 & $0 \%$ & 20 & $10 \%$ & 94 & $47 \%$ & 58 & $29 \%$ & 28 & $14 \%$ & 694 & 3.5 & \\
\hline \multirow{2}{*}{$\begin{array}{c}\text { Personal } \\
\text { Traits }\end{array}$} & Y7 & 0 & $0 \%$ & 11 & $6 \%$ & 78 & $39 \%$ & 80 & $40 \%$ & 31 & $16 \%$ & 731 & 3.7 & \multirow{2}{*}{3.7} \\
\hline & $\mathrm{Y} 8$ & 0 & $0 \%$ & 0 & $0 \%$ & 76 & $38 \%$ & 87 & $44 \%$ & 37 & $19 \%$ & 761 & 3.8 & \\
\hline
\end{tabular}

Source: Data Processing 2020

Table 9 shows that most of the respondents answered agree (39\%). The result of the analysis on the average of all respondents' answers to the employee performance variable is 3.8. The results above indicate that the highest employee performance is in the work result indicator, namely 4.2, and the lowest is the work behavior indicator, which is 3.6. These results can be illustrated in the following diagram:

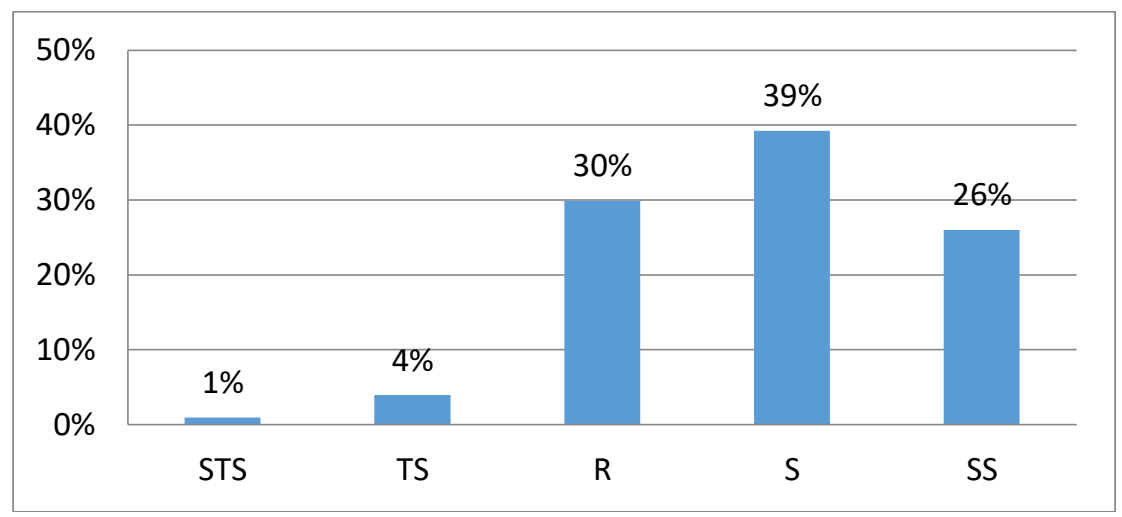

Source: Data Processing 2020

Figure 3. Distribution of Answers on Employee Performance Variables 
The diagram above shows that the results of the distribution of the highest employee performance answers are in agreement, namely 39\%, and the lowest results strongly disagree, namely $1 \%$.

Some things to consider in terms of performance are work results, work behavior, and personal characteristics. Every company or organization must have goals, target achievement that can be seen from employees' work.

To achieve work efficiency, the targets achieved and the quality of work must be supported by employee work behavior and employee personal characteristics and how honesty of employees in working employee creativity in workers must be assessed. The company always evaluates periodically (Sutrisno, 2010).

The results of descriptive analysis of respondents' answers to each indicator of organizational culture variables are presented in the following table:

Table 10. Results of the Descriptive Analysis of Organizational Culture Variables

\begin{tabular}{|c|c|c|c|c|c|c|c|c|c|c|c|c|c|c|}
\hline \multirow{3}{*}{ Indicator } & \multirow{3}{*}{ Item } & \multicolumn{10}{|c|}{ Answer Score } & \multirow{3}{*}{ Amount } & \multirow{3}{*}{$\begin{array}{c}\text { Mean } \\
\text { Item }\end{array}$} & \multirow{3}{*}{$\begin{array}{c}\text { Mean } \\
\text { Indicator }\end{array}$} \\
\hline & & \multicolumn{2}{|c|}{ (1) SD } & \multicolumn{2}{|c|}{ (2) $\mathrm{Di}$} & \multicolumn{2}{|c|}{ (3) Do } & \multicolumn{2}{|c|}{ (4) A } & \multicolumn{2}{|c|}{ (5) SA } & & & \\
\hline & & $F$ & $\%$ & $\mathrm{~F}$ & $\%$ & $\mathrm{~F}$ & $\%$ & F & $\%$ & F & $\%$ & & & \\
\hline \multirow{2}{*}{$\begin{array}{c}\text { Self } \\
\text { assurance }\end{array}$} & $\mathrm{Z1}$ & 0 & $0 \%$ & 4 & $2 \%$ & 57 & $29 \%$ & 93 & $47 \%$ & 46 & $23 \%$ & 781 & 3.9 & \multirow{2}{*}{4.0} \\
\hline & $\mathrm{Z} 2$ & 0 & $0 \%$ & 5 & $3 \%$ & 45 & $23 \%$ & 71 & $36 \%$ & 79 & $40 \%$ & 824 & 4.1 & \\
\hline \multirow[b]{2}{*}{$\begin{array}{l}\text { Assertiveness } \\
\text { in attitude } \\
\text { (decisiveness) }\end{array}$} & $\mathrm{Z3}$ & 0 & $0 \%$ & 12 & $6 \%$ & 60 & $30 \%$ & 75 & $38 \%$ & 53 & $27 \%$ & 769 & 3.8 & \multirow[b]{2}{*}{4.0} \\
\hline & $\mathrm{Z} 4$ & 0 & $0 \%$ & 3 & $2 \%$ & 17 & $9 \%$ & 111 & $56 \%$ & 69 & $35 \%$ & 846 & 4.2 & \\
\hline \multirow{2}{*}{$\begin{array}{c}\text { Supervisory } \\
\text { ability }\end{array}$} & Z5 & 0 & $0 \%$ & 19 & $10 \%$ & 59 & $30 \%$ & 78 & $39 \%$ & 44 & $22 \%$ & 747 & 3.7 & \multirow{2}{*}{3.7} \\
\hline & $\mathrm{Z6}$ & 0 & $0 \%$ & 19 & $10 \%$ & 65 & $33 \%$ & 83 & $42 \%$ & 33 & $17 \%$ & 730 & 3.7 & \\
\hline \multirow{2}{*}{ Inteligence } & $\mathrm{Z7}$ & 0 & $0 \%$ & 30 & $15 \%$ & 45 & $23 \%$ & 72 & $36 \%$ & 53 & $27 \%$ & 748 & 3.7 & \multirow{2}{*}{3.7} \\
\hline & $\mathrm{Z} 8$ & 0 & $0 \%$ & 10 & $5 \%$ & 95 & $48 \%$ & 47 & $24 \%$ & 48 & $24 \%$ & 733 & 3.7 & \\
\hline \multirow{2}{*}{ Initiative } & $\mathrm{Z9}$ & 0 & $0 \%$ & 13 & $7 \%$ & 44 & $22 \%$ & 88 & $44 \%$ & 55 & $28 \%$ & 785 & 3.9 & \multirow{2}{*}{3.9} \\
\hline & $\mathrm{Z} 10$ & 0 & $0 \%$ & 3 & $2 \%$ & 58 & $29 \%$ & 81 & $41 \%$ & 58 & $29 \%$ & 794 & 4.0 & \\
\hline \multirow{2}{*}{$\begin{array}{c}\text { Need for } \\
\text { achievement }\end{array}$} & $\mathrm{Z} 11$ & 0 & $0 \%$ & 0 & $0 \%$ & 56 & $28 \%$ & 97 & $49 \%$ & 47 & $24 \%$ & 791 & 4.0 & \multirow{2}{*}{3.9} \\
\hline & $\mathrm{Z12}$ & 0 & $0 \%$ & 3 & $2 \%$ & 71 & $36 \%$ & 68 & $34 \%$ & 58 & $29 \%$ & 781 & 3.9 & \\
\hline \multirow{2}{*}{$\begin{array}{l}\text { Need for self } \\
\text { actualization }\end{array}$} & $\mathrm{Z} 13$ & 0 & $0 \%$ & 31 & $16 \%$ & 49 & $25 \%$ & 72 & $36 \%$ & 48 & $24 \%$ & 737 & 3.7 & \multirow{2}{*}{3.8} \\
\hline & Z14 & 0 & $0 \%$ & 18 & $9 \%$ & 45 & $23 \%$ & 90 & $45 \%$ & 47 & $24 \%$ & 766 & 3.8 & \\
\hline \multirow{2}{*}{$\begin{array}{c}\text { Need for } \\
\text { power }\end{array}$} & Z15 & 0 & $0 \%$ & 34 & $17 \%$ & 61 & $31 \%$ & 58 & $29 \%$ & 47 & $24 \%$ & 718 & 3.6 & \multirow{2}{*}{3.6} \\
\hline & $\mathrm{Z} 16$ & 0 & $0 \%$ & 17 & $9 \%$ & 76 & $38 \%$ & 58 & $29 \%$ & 49 & $25 \%$ & 739 & 3.7 & \\
\hline \multirow{2}{*}{$\begin{array}{c}\text { Need for } \\
\text { reward }\end{array}$} & $\mathrm{Z} 17$ & 0 & $0 \%$ & 48 & $24 \%$ & 53 & $27 \%$ & 55 & $28 \%$ & 44 & $22 \%$ & 695 & 3.5 & \multirow{2}{*}{3.6} \\
\hline & $\mathrm{Z} 18$ & 0 & $0 \%$ & 3 & $2 \%$ & 96 & $48 \%$ & 64 & $32 \%$ & 37 & $19 \%$ & 735 & 3.7 & \\
\hline \multirow{2}{*}{$\begin{array}{l}\text { Need for } \\
\text { security }\end{array}$} & Z19 & 0 & $0 \%$ & 3 & $2 \%$ & 55 & $28 \%$ & 97 & $49 \%$ & 45 & $23 \%$ & 784 & 3.9 & 9 \\
\hline & $\mathrm{Z} 20$ & 0 & $0 \%$ & 4 & $2 \%$ & 69 & $35 \%$ & 71 & $36 \%$ & 56 & $28 \%$ & 779 & 3.9 & 3.9 \\
\hline
\end{tabular}

Source: Data Processing 2020

Table 10 shows that most respondents answered agree (38\%). The analysis results on the average of all respondents' answers to the organizational culture variable were 3.8. The results above show that the highest corporate culture is on self-assurance and assertiveness in attitudes, which is 4.0 , and the lowest is on the 
indicators of the need for positions and the need for rewards, which are 3.6. These results can be illustrated in the following diagram:

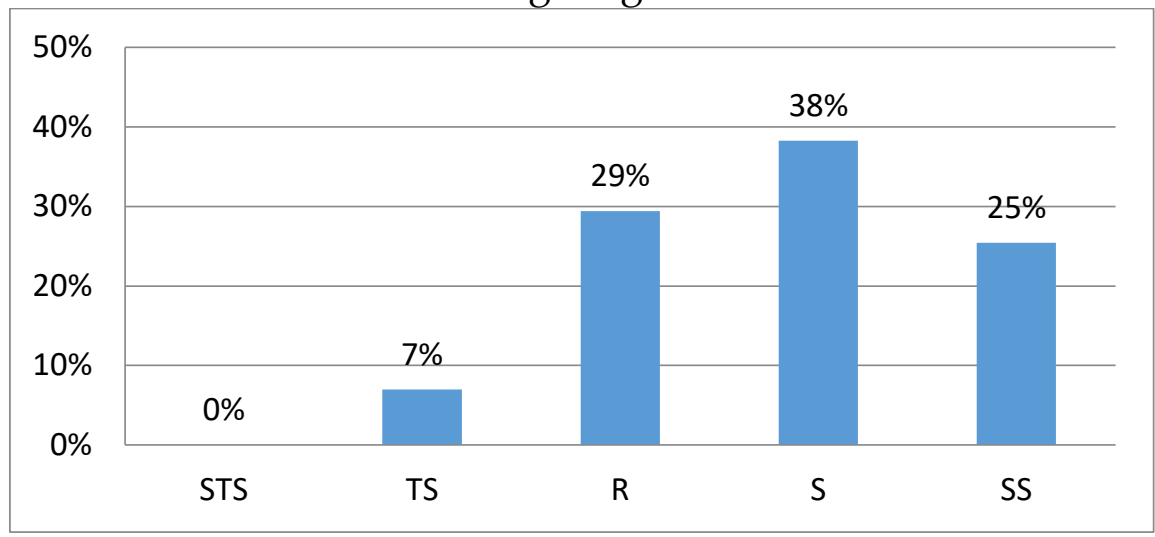

Source: Data Processing 2020

Figure 4. Distribution of Answers on Organizational Culture Variables

In the diagram above, it shows that the distribution results of the highest organizational culture answers on agreeing answers are $38 \%$ and the lowest results on the disagree answers are $7 \%$.

\section{Training Validity Test}

The following is the result of SPSS processing as shown in Table 11:

Table 11 Validity Test of Training Variables

\begin{tabular}{|c|c|c|c|}
\hline Question & R count & R Table & Information \\
\hline X1.1 & 0.607 & 0.361 & Valid \\
\hline X1.2 & 0.563 & 0.361 & Valid \\
\hline X1.3 & 0.549 & 0.361 & Valid \\
\hline X1.4 & 0.852 & 0.361 & Valid \\
\hline X1.5 & 0.872 & 0.361 & Valid \\
\hline X1.6 & 0.760 & 0.361 & Valid \\
\hline X1.7 & 0.698 & 0.361 & Valid \\
\hline X1.8 & 0.715 & 0.361 & Valid \\
\hline
\end{tabular}

Source: Data Processing 2020

From this processing, the results obtained that each question has a value of $\mathrm{r}_{\text {count }}>\mathrm{r}_{\text {table; }}$ thus that each question can be interpreted as meeting the requirements to be said to be valid.

\section{Competency Validity Test}

The following is the result of SPSS processing shown in Table 12:

Table 12: Test the Validity of Competency Variables

\begin{tabular}{|c|c|c|c|}
\hline Question & R count & R Table & Information \\
\hline X2.1 & 0.795 & 0.361 & Valid \\
\hline X2.2 & 0.715 & 0.361 & Valid \\
\hline X2.3 & 0.696 & 0.361 & Valid \\
\hline X2.4 & 0.716 & 0.361 & Valid \\
\hline
\end{tabular}




\begin{tabular}{|l|l|l|l|} 
X2.5 & 0.750 & 0.361 & Valid \\
\hline X2.6 & 0.610 & 0.361 & Valid \\
\hline X2.7 & 0.771 & 0.361 & Valid \\
\hline X2.8 & 0.767 & 0.361 & Valid \\
\hline X2.9 & 0.792 & 0.361 & Valid \\
\hline
\end{tabular}

Source: Data Processing 2020

From this processing, the results obtained that each question has a value of $r_{\text {count }}>r_{\text {table; }}$ thus that each question can be interpreted as meeting the requirements to be said to be valid.

\section{Competency Validity Test}

The following is the result of SPSS processing shown in Table 13:

Table 13: Validity Test of Compensation Variables

\begin{tabular}{|c|c|c|c|}
\hline Question & R count & R Table & Information \\
\hline X3.1 & 0.732 & 0.361 & Valid \\
\hline X3.2 & 0.671 & 0.361 & Valid \\
\hline X3.3 & 0.580 & 0.361 & Valid \\
\hline X3.4 & 0.743 & 0.361 & Valid \\
\hline X3.5 & 0.751 & 0.361 & Valid \\
\hline X3.6 & 0.864 & 0.361 & Valid \\
\hline X3.7 & 0.644 & 0.361 & Valid \\
\hline X3.8 & 0.608 & 0.361 & Valid \\
\hline
\end{tabular}

Source: Data Processing 2020

From this processing, the results obtained that each question has a value of $\mathrm{r}_{\text {count }}>\mathrm{r}_{\text {table; }}$ thus that each question can be interpreted as meeting the requirements to be said to be valid.

\section{Employee Performance Validity Test}

The following is the result of SPSS processing as shown in Table 14:

Table 14. Validity Test of Employee Performance Variables

\begin{tabular}{|c|c|c|c|}
\hline Question & R count & R table & Information \\
\hline Y1 & 0.428 & 0.361 & Valid \\
\hline Y2 & 0.476 & 0.361 & Valid \\
\hline Y3 & 0.814 & 0.361 & Valid \\
\hline Y4 & 0.605 & 0.361 & Valid \\
\hline Y5 & 0.657 & 0.361 & Valid \\
\hline Y6 & 0.568 & 0.361 & Valid \\
\hline Y7 & 0.768 & 0.361 & Valid \\
\hline Y8 & 0.846 & 0.361 & Valid \\
\hline
\end{tabular}

Source: Data Processing 2020 
From this processing, the results obtained that each question has a value of $r_{\text {count }}>\mathrm{r}_{\text {table; }}$ thus that each question can be interpreted as meeting the requirements to be said to be valid.

\section{Organizational Culture Validity Test}

The following is the result of SPSS processing shown in Table 5:

Table 15. Test the Validity of Organizational Culture Variables

\begin{tabular}{|c|c|c|c|}
\hline Question & R count & R table & Information \\
\hline Z1 & 0.564 & 0.361 & Valid \\
\hline Z2 & 0.484 & 0.361 & Valid \\
\hline Z4 & 0.485 & 0.361 & Valid \\
\hline Z5 & 0.680 & 0.361 & Valid \\
\hline Z6 & 0.609 & 0.361 & Valid \\
\hline Z7 & 0.421 & 0.361 & Valid \\
\hline Z8 & 0.579 & 0.361 & Valid \\
\hline Z9 & 0.396 & 0.361 & Valid \\
\hline Z10 & 0.525 & 0.361 & Valid \\
\hline Z11 & 0.506 & 0.361 & Valid \\
\hline Z12 & 0.550 & 0.361 & Valid \\
\hline Z13 & 0.567 & 0.361 & Valid \\
\hline Z14 & 0.476 & 0.361 & Valid \\
\hline Z15 & 0.512 & 0.361 & Valid \\
\hline Z16 & 0.481 & 0.361 & Valid \\
\hline Z17 & 0.490 & 0.361 & Valid \\
\hline Z18 & 0.681 & 0.361 & Valid \\
\hline Z19 & 0.485 & 0.361 & Valid \\
\hline Z20 & 0.841 & 0.361 & Valid \\
\hline
\end{tabular}

Source: Data Processing 2020

From this processing, the results obtained that each question has a value of $r_{\text {count }}>\mathrm{r}_{\text {table; }}$ thus that each question can be interpreted as meeting the requirements to be said to be valid.

\section{Training Reliability Test}

The following is the result of SPSS processing to test the reliability of the training variables shown in the following table:

Table 16. Reliability Test of Training Variables

\begin{tabular}{|c|c|c|}
\hline Variable & Cronbach Alpha & Conclusion \\
\hline Training Variables (X1) & 0.842 & Reliable \\
\hline
\end{tabular}

Source: Data Processing 2020 
From this processing, the results obtained that each question has a Cronbach's Alpha value $>0.70$. Thus, each statement can be interpreted as meeting the requirements reliably.

\section{Competency Reliability Test}

The following is the result of SPSS processing to test the reliability of the training variables shown in the following table:

Table 17. Compensation Variable Reliability Test

\begin{tabular}{|c|c|c|}
\hline Variable & Cronbach Alpha & Conclusion \\
\hline Compensation Variable $(\mathrm{X} 3)$ & 0.846 & Reliable \\
\hline
\end{tabular}

Source: Data Processing 2020

From this processing, the results obtained that each question has a Cronbach's Alpha value $>0.70$. Thus, each statement can be interpreted as meeting the requirements reliably.

\section{Employee Performance Reliability Test}

The following is the result of SPSS processing to test the reliability of the training variables shown in the following table:

Table 18. Reliability Test of Employee Performance Variables

\begin{tabular}{|c|c|c|}
\hline Variable & Cronbach Alpha & Conclusion \\
\hline Employee Performance Variables (Y) & 0.794 & Reliable \\
\hline
\end{tabular}

Source: Data Processing 2020

From this processing, the results obtained that each question has a Cronbach's Alpha value $>0.70$. Thus, each statement can be interpreted as meeting the requirements reliably.

\section{Organizational Culture Reliability Test}

The following is the result of SPSS processing to test the reliability of the training variables shown in the following table:

Table 19. Reliability Test of Organizational Culture Variables

\begin{tabular}{|c|c|c|}
\hline Variable & Cronbach Alpha & Conclusion \\
\hline Organizational Culture Variables $(Z)$ & 0.8629 & Reliable \\
\hline
\end{tabular}

Source: Data Processing 2020

From this processing, the results obtained that each question has a Cronbach's Alpha value $>0.70$. Thus, each statement can be interpreted as meeting the requirements reliably.

From the results of the data processing above, it can be concluded that: First, Pre-service Education and Training/Basic Training for CPNS has a positive and significant effect on the new Civil Servant Organizational Culture at the Ministry of Health. This is evidenced by the $t$ value of 3.63, which is greater than the specified critical limit, which is \pm 1.96 . It can be interpreted that the improvement of Civil 
Servant Training/Basic Training for CPNS in terms of 1) Curriculum, 2) Methods, 3) Trainers, and 4) Evaluation/Assessment, will directly affect the new Civil Servant Organizational Culture at the Ministry of Health.

Second, competence has a positive and significant effect on the new Civil Service Organization Culture at the Ministry of Health. This is evidenced by the $t$ value of 3.65 , which is greater than the specified critical limit, which is \pm 1.96 . It can be interpreted that competence in terms of 1) Knowledge, 2) Skills, and 3) Ability will directly influence the new Civil Servant Organizational Culture at the Ministry of Health.

Third, Pre-Position Training/Basic Training for CPNS, Competence, and Compensation has a positive and significant effect on the new Civil Servant Organizational Culture at the Ministry of Health. This is evidenced by the Fcount value of 47,310 . Due to the calculated F value $(47,310)>\mathrm{F}$ table $(2.651)$. It can be interpreted that the pre-service education and training/basic training for civil servants, competence, and compensation will directly influence the new civil servant organizational culture at the Ministry of Health.

Fourth, Organizational Culture has a positive and significant effect on new Civil Servants' performance at the Ministry of Health. This is evidenced by the $t$ value of 6.38 , which is greater than the specified critical limit, which is \pm 1.96 . It can be interpreted that an increase in organizational culture in terms of 1) Self-assurance; 2) Assertiveness in attitude; 3) Supervision ability; 4) Emotional intelligence; 5) Initiative, 6) Need for achievement; 7) Need for self-actualization; 8) Need about positions; 9) Need for rewards; 10) The need for a sense of security, will directly affect the performance of new civil servants in the Ministry of Health.

Fifth, Pre-Position Training/Basic Training for CPNS has a positive and significant effect on new Civil Servants' performance at the Ministry of Health. This is evidenced by the $t$ value of 5.28 , which is greater than the specified critical limit, which is \pm 1.96 . It can be interpreted that the improvement of CPNS Pre-service Education and Training in terms of 1) Curriculum; 2) Methods; 3) Trainers; and 4) Evaluation /Assessment will directly affect the performance of new civil servants at the Ministry of Health (Yulianto, 2018).

Sixth, competence has a positive and significant effect on new Civil Servants' performance at the Ministry of Health. This is evidenced by the value of $t$ count 4.25 , which is greater than the specified critical limit, namely \pm 1.96 . It can be interpreted that competence in terms of 1) Knowledge, 2) Skills, and 3) Ability will directly affect the performance of new Civil Servants at the Ministry of Health (Ansyari, 2012).

Seventh, compensation has a positive and significant effect on new Civil Servants' performance at the Ministry of Health. This is evidenced by the $t$ value of 5.56 , which is greater than the specified critical limit, which is \pm 1.96 . It can be interpreted that compensation in terms of 1) Wages/salaries; 2) Incentives/Bonuses; 3) Allowances, and 4) Facilities will directly affect the performance of new civil servants in the Ministry of Health (Yetti Sembiring, 2016). 
Eighth Organizational Culture, Pre-Position Training/Basic Training for CPNS, Competence, and Compensation has a significant effect on the Performance of new Civil Servants at the Ministry of Health. This is evidenced by the Fcount value of 47,310 . Due to $F_{\text {count }}$ of 131,806 . Due to the calculated F value $(131,806)>F$ table $(2,651)$. It can be interpreted that the pre-service education and training / basic training for civil servants, competence, and compensation will directly affect new civil servants' performance at the Ministry of Health. The results of this study are in line with research conducted by Research (Jumadin, Buyung, \& Aidin, 2019) with the title "The Effect of Training, Competence, Motivation, and Organizational Culture on Employee Performance" showing that training, competence, motivation, and organizational culture have a significant positive effect on performance.

Ninth, Pre-Position Training/Basic Training for CPNS has a positive and significant effect on new Civil Servants' performance at the Ministry of Health mediated by Organizational Culture. This is evidenced by the $t$ value of 3.120, which is greater than the specified critical limit, which is \pm 1.96 . It can be interpreted that the improvement of CPNS Pre-service Training/Basic Training in terms of 1) Curriculum; 2) Methods; 3) Trainers; and 4) Evaluation/Assessment, will indirectly affect through organizational culture on the performance of new Civil Servants at the Ministry of Health.

Tenth, competence has a positive and significant effect on new Civil Servants' performance at the Ministry of Health mediated by Organizational Culture. This is evidenced by the $t$ value of 3.112, which is greater than the specified critical limit, which is \pm 1.96 . It can be interpreted that competence in terms of 1) Knowledge; 2) Skills; and 3) Ability will affect indirectly through organizational culture on the performance of new Civil Servants at the Ministry of Health Bar (2009).

Eleventh, compensation has a positive and significant effect on new Civil Servants' performance at the Ministry of Health mediated by Organizational Culture. This is evidenced by the $t$ value of 4.118 , which is greater than the specified critical limit, which is \pm 1.96 . It can be interpreted that compensation in terms of 1 ) Wages/Salaries, 2) Incentives/Bonuses, 3) Allowances, and 4) Facilities will indirectly affect organizational culture on the performance of new civil servants at the Ministry of Health.

\section{CONCLUSION}

Based on the results of the research and data analysis that has been carried out, the conclusions of this study are as follows: (1) Training has been shown to have a positive and significant effect on the organizational culture within the Ministry of Health, meaning that the increasing training implemented by the Ministry of Health will improve the corporate culture of employees Ministry of Health. This influence is determined by the training held by BBPK Jakarta for Ministry of Health employees to form employees with an excellent organizational culture; and (2) Competence is proven to have a positive and significant effect on the organizational culture within the Ministry of Health, meaning that the increased competence applied by the 
Ministry of Health will improve the corporate culture of the Ministry of Health's employees. This influence is determined by the existence of training held by BBPK Jakarta to improve employee competence which has an impact on forming employees with an excellent organizational culture;

\section{REFERENCES}

1. Amir, M. T. (2017). Perilaku Organisasi. Jakarta: Kencana.

2. Ansyari. (2012). Pengaruh Budaya Organisasi, Komitmen dan Kompetensi Terhadap Kinerja Pimpinan Daerah Muhammadiyah Asahan. Jakarta: Universitas Terbuka.

3. Bahtiar, Dwi, H., \& Tabrani. (2017). Pengaruh Kompetensi Komunikasi, dan Budaya Organisasi Terhadap Kinerja Pegawai Melalui Kepuasan Pegawai Pada Dinas Pendapatan dan Pengelola Keuangan Kabupaten Brebes. Multiplier, I(2): 21-36.

4. Busro, M. (2018). Teori-Teori Manajemen Sumber Daya Manusia. Jakarta: Prenamedia Group.

5. Dessler, G. (2015). Manajemen Sumber Daya Manusia. Jakarta: Salemba Empat.

6. Dhermawan. (2012). Pengaruh Motivasi, Lingkungan Kerja, Kompetensi, dan Kompensasi Terhadap Kepuasan Kerja dan Kinerja Pegawai di Lingkungan Kantor Dinas Pekerjaan Umum Provinsi Bali. Jurnal Manajemen, Strategi Bisnis, dan Kewirausahaan, 6(2), 173-184.

7. Febrina (2019). "Model of Job satisfaction and Employee Performance at Bank Jatim Malang Branch. IOSR Journal of Business and Management, 21(9), 13-22.

8. Girsang, W. (2019). Pengaruh Budaya Organisasi dan Komitmen Organisasi Terhadap Kinerja Karyawan. Jurnal Riset Manajemen dan Bisnis (JRMB) Fakultas Ekonomi UNIAT, 4(1), 119-126.

9. Katidjan. (2018). The Effect of Competence, Training, and Compensation to Employment Performance. European Research Studies Journal, XXI(3), 280-292.

10. Kesehatan, K. (2019). Laporan Kinerja. Jurnal Abdimas Dewantara, 53(9), 16891699.

11. Kurniawan. (2018). The Effect of Competence and Motivation on Employee Performance Through Employees Capabilities on PT Binasinar Amity. International Journal of Research Science and Management, 5(6), 48-60.

12. Lembaga Administrasi Negara. (2018). Peraturan Lembaga Administrasi Negara Nomor 12 Tahun 2018. Jakarta: Kementerian Hukum dan Hak Asasi Manusia.

13. Manurung, Y. V. (2013). Pengaruh Pelatihan, Motivasi, Kepemimpinan dan Budaya Organisasi Terhadap Kinerja Karyawan PT. Karya Dewiputra. Jakarta: Universitas Terbuka.

14. Maryesa. (2016). Analisis Peran Remunerasi dan Budaya Organisasi Terhadap Kompetensi Pegawai Guna Meningkatkan Kinerja Pegawai di Lembaga Penerbangan dan Antariksa Nasional. Manajemen IKM 11(2), 159-172.

15. Mawardi. (2010). Pengaruh Pelatihan Terhadap Kinerja Pegawai Negeri Sipil (Studi pada Dinas Kesehatan Kabupaten Kapuas Hulu). Tesis. Pontianak: Universitas Terbuka. 
16. Mondy, R. W. (2008). Manajemen Sumber Daya Manusia. Jakarta: Erlangga.

17. Muharam, A. (2019). "Efektivitas Program Pembekalan/Pelatihan Bagi Calon PNS Sebagai Dasar untuk Pengembangan SDM ASN yang Profesional." Simpul Perencana (Bappenas), 1(1), 4-5.

18. Ningsi, C. A., Alhabsji, T., \& Utami, H. N. (2016). Pengaruh Pelatihan dan Promosi Terhadap Motivasi dan Kinerja Karyawan (Studi pada Karyawan PT. PLN (Persero) Area Kendari). Jurnal Ilmiah Ilmu Administrasi Publik, 5(2), 131.

19. Pemerintah Indonesia. (2014). Undang-Undang Nomor 5 Tahun 2014 Tentang Aparatur Sipil Negara. Jakarta: Sekretariat Negara.

20. Pujimulyatama, A. (2014). Analisis Pengentasan Kemiskinan dalam Prespektif Peran Gender di Pedesaan. Jurnal Ekonomi Pembangunan. 12(1), 86-98.

21. Robbins, S. P., \& Timothy A. J. (2015). Perilaku Organisasi. Jakarta: Salemba Empat.

22. Sanusi, A. (2011). Metodologi Penelitian Bisnis. Jakarta: Salemba Empat.

23. Saraswati, E., \& Subagio, I. S. (2019). Pengaruh kompetensi dan pemahaman sistem informasi akuntansi serta motivasi terhadap kinerja karyawan pada RSUD. Prof. Dr. Margono Soekarjo Purwokerto. Journal of Law, English, and Economics, 1(1), 11-27.

24. Sari, R. N., Sjahruddin, H., \& Razak, N. (2018). Pengaruh Kompetensi Terhadap Kinerja Dimoderasi Profesionalisme Karyawan. Jurnal Ilmiah Ilmu Administrasi Publik 1(1), 19-30.

25. Sembiring, Y. (2016). Pengaruh Pemberian Pendidikan Pelatihan dan Kompensasi Terhadap Kinerja Pegawai Negeri Sipil pada Sekretariat Daerah Kabupaten Tapanuli Tengah. Jakarta: Universitas Terbuka.

26. Setiawan, M. B., \& Abdul, H. (2013). Indeks Pembangunan Manusia Indonesia. Jurnal Economia. 2(1), 18-26.

27. Sinambela, L. P. (2016). Manajemen Sumber Daya Manusia. Jakarta: Bumi Aksara.

28. Sugiyono. (2012). Metode Penelitian Kuantitatif, Kualitatif dan RED. Bandung: Alfabeta.

29. Sultana. (2012). Impact of Training on Employee Performance: A Study of Telecommunication Sector in Pakistan. Interdisciplinary Journal of Contemporary Research in Business, 4(6), 646-661.

30. Sutrisno, E. (2010). Budaya Organisasi. Jakarta: Kencana.

31. Yulianto, W. (2018). Kementerian Kelautan dan Perikanan. Balai Diklat Aparatur Kementerian Kelautan dan Perikanan, 9(1), 67-79. 